\title{
Sosialisasi Pendidikan Berorganisasi dan Pendidikan Karakter di Desa Jajaran Baru II Kecamatan Megang Sakti Kabupaten Musirawas
}

\author{
Agus Susilo ${ }^{1}$, Akmal Rijal ${ }^{2^{*}}$ \\ 1, 2, STKIP PGRI Lubuklinggau \\ 12agussusilo594@yahoo.co.id, ${ }^{2}$ akmalrijal3@gmail.com
}

\begin{abstract}
Abstrak
Pendidikan berorganisasi dan pendidikan karakter bagi generasi muda sangat diperlukan bagi masyarakat di Desa Jajaran Baru II Kecamatan Megang Sakti Kabupaten Musi Rawas agar dapat memilah perkembangan zaman yang semakin pesat saat ini. Peran orangtua, lingkungan dan sekolah sangat memberikan dampak terhadap perkembangan pribadi karakter anak-anak muda di Desa Jajaran Baru. Workshop diselenggarakan dengan ceramah, tanya jawab, dan memberi solusi. Ceramah dan Tanya Jawab. Metode ini bertujuan untuk menyampaikan rangkaian teori tentang cara berorganisasi yang baik dan materi pendidikan karakter yang tertuang dalam slide video dengan materi konsep pendidikan berorganisasi, pendidikan karakter, dan strategi pendampingan pendidikan berorganisasi yang baik. Dukungan lembaga desa dan masyarakat Desa Jajaran Baru Kecamatan Megang Sakti menjadi tolak ukur dilaksanakan pengabdian pada masyarakat oleh DosenDosen STKIP PGRI Lubuklinggau. Dalam menyampaikan paparannya dalam kegiatan pengabdian masyarakat di Desa Jajaran Baru II Kecamatan Megang Sakti Kabupaten Musi Rawas, peserta yang diharapkan hadir sekitar 15 orang. Kriteria sasaran yang akan mengikuti sosialisasi pendidikan berorganisasi dan pendidikan karakter di Desa Jajaran Baru II Kecamatan Megang Sakti Kabupaten Musi Rawas merupakan para generasi muda dan tua yang terdiri dari para masyarakat biasa, perangkat Desa, Karang Taruna, dan mahasiswa. bahwa seluruh kegiatan menunjang peningkatan pengetahuan dan keterampilan dalam keberlangsungan membangun pendidikan berorganisasi dan pendidikan karakter bagi genarasi muda terhadap pengaruh era industry yang semakin luas agar dapat menjadi generasi muda yang berilmu dan mampu memfilter segala pengaruh luar yang masuk dilingkungan ekonomi, politik, sosial dan budaya masyarakat.
\end{abstract}

Kata Kunci: sosialisasi, pendidikan berorganisasi, pendidikan karakter

\section{Pendahuluan}

Indikator dari pendidikan berorganisasi dan pendidikan karakter dalammasyarakat adalah kemampuan dan kebebasan untuk membuat pilihan yang terbaik dalam menentukan atau memperbaiki kehidupannya. Konsep pemberdayaan mencakup pengertian pembangunan masyarakat (community development) dan pembangunan yang bertumpu pada masyarakat (community-based development). Artinya masyarakat dibina dan dilatih agar mem punyai pengetahuan, keahlian, dan keterampilan yang dapat 
dimanfaatkan secara ekonomis sehingga masyarakat dapat maju dan memberdayakan dirinya melalaui usaha-usaha ekonomi yang produktif. Sosialisasi pendidikan berorganisasi dan pendidikan karakter bagi masyarakat berarti kemampuan seseorang untuk memahami dan mengendalikan keadaan sosial dan ekonomi serta lingkungan yang sangat diper lukan dalam upaya meningkatkan kesejahterannya di masyarakat, dengan kata lain proses pemberdayaan adalah setiap usaha pendidikan yang bertujuan untuk membangkitkan kesadaran dan keinginan untuk memiliki pengetahuan, keterampilan, dan kemampuan yang pada akhirnya akan memiliki kemampuan untuk memperbaiki dan meningkatkan kesejahteraannya. Masyarakat merupakan kelompok sosial yang memiliki potensi yang dapat menggunakan kemampuan dirinya dalam mengem bangkan berbagai potensi yang dapat memberikan nilai tambah dalam kehidupannya.

Permasalahannya adalah peran masyarakat seringkali tidak tanggap dan mengetahui mengenai masalah kehidupannya sendiri. Oleh karena itu, diperlukan sebuah strategi program pendidikan luar sekolah yang tepat agar dapat membangun kesadaran masyarakat untuk terlibat dalam proses pemberdayaan masyarakat yang efektif dan efisien (Subekti, 2018: 149-150). Setiap perguruan tinggi diharapkan dapat mengelola penelitian yang memenuhi standar yang telah dijelaskan dalam Permenristekdikti Nomor 44 Tahun 2015 tentang Standar Nasional Pendidikan Tinggi terkait dengan ruang lingkup dan penjelasan Standar Nasional Penelitian sebagai berikut.

a. Standar arah, kegiatan penelitian mengacu pada Renstra Penelitian dan Pengabdian pada Masyarakat STKIP PGRI Lubuklinggau.

b. Standar proses, kegiatan penelitian dan pengabdian direncanakan, dilaksanakan, dikendalikan, dan ditingkatkan sesuai dengan sistem peningkatan mutu penelitian dan pengabdian kepada masyarakat yang berkelanjutan.

c. Standar hasil, kegiatan penelitian memenuhi kaidah ilmiah universal, didokumentasi, didesimenasikan melalui forum ilmiah ditingkat lokal, nasional, internasional, serta dapat dipertanggungjawabkan, standar hasil kegiatan pengabdian kepada masyarakat harus berhasil menciptakan inovasi teknologi untuk mendorong ekonomi dan memenuhi kebutuhan masyarakat.

d. Standar kompetensi, kegiatan penelitian dilakukan oleh peneliti yang berkompeten di bidangnya dan untuk kegiatan pengabdian kepada masyarakat dilakukan dari hasil penelitian yang sesuai dengan kaedah ilmiah.

e. Standar pendanaan, kegiatan penelitian dan pengabdian kepada masyarakat dilakukan melaui mekanisme hibah blok dan kompetisi yang didasarkan pada prinsip otonomi dan akuntabilitas.

f. Standar Sarana dan Prasarana, kegiatan penelitian dan pengabdian kepada masyarakat didukung oleh sarana dan prasarana yang mampu menghasilkan temuan ilmiah dan solusi masalah dalam masyarakat.

g. Standar outcome, kegiatan penelitian dan pengabdian kepada masyarakat harus berdampak positif pada pembangunan masyarakat bangsa dan negara diberbagai sektor. 
Kegiatan pengabdian masyarakat ini bekerjasama dengan Karang Taruna Desa Jajaran Baru II dan mahasiswa KKN STKIP PGRI Lubuklinggau, serta Perangkat Desa Jajaran Baru II. Pengabdian ini akan mencoba meningkatan kapasitas organisasi di dalam masyarakat dan pendidikan karakter yang saat ini menjadi perbincangan bagi masyarakat Jajaran Baru II. Tim Program Pengabdian Pada Masyarakat memprioritaskan pada kehidupan berorganisasi yang baik yang dilandasi karakter yang mulia dan berbudi luhur dilingkungan masyarakat Jajaran Baru II. Selain itu dalam kehidupan berorganisasi juga akan memberikan pengarahan dan bimbingan kepada masyarakat khususnya generasi muda Desa Jajaran Baru II mengenai pentingnya membentuk sebuah organisasi yang lebih terstruktur, terarah dan mampu memberikan manfaat yang lebih banyak kepada masyarakat secara inklusif dan berkelanjutan dalam jangka panjang dengan tujuan akhir menjadikan warga masyarakat Desa Jajaran Baru memiliki harapan yang tinggi dalam berorganisasi dan berpendidikan karakter.

Menurut Buku Pedoman Akademik STKIP PGRI Lubuklinggau, kegiatan seminar, workshop dapat mengambil tema berbagai bidang kajian kependidikan. Kegiatan ini dapat diselenggarakan mulai dari tingkat program studi sampai pada tingkat yayasan. Untuk tingkat prodi kegiatan workshop ini dapat dilaksanakan paling tidak satu kali dalam satu semester. Di dalam kerangka inilah, maka Prodi PGSD bermaksud menyenggarakan sebuah sosialisasi di Desa Jajaran Baru II dengan tema: "Sosialisasi Pendidikan Berorganisasi dan Pendidikan Karakter di Desa Jajaran Baru II Kecamatan Megang Sakti Kabupaten Musi Rawas".

Tujuan program PKM ini adalah untuk meningkatkan peran dan partisipasi STKIP PGRI Lubuklinggau dalam membangun pendidikan berorganisasi dan pendidikan karakter bagi genarasi muda terhadap pengaruh era industri yang semakin luas agar dapat menjadi generasi muda yang berilmu dan mampu memfilter segala pengaruh luar yang masuk dilingkungan ekonomi, politik, sosial dan budaya masyarakat, mendiseminasikan hasil-hasil pengabdian pada masyarakat STKIP PGRI Lubuklinggau yang dapat dimanfaatkan untuk memperkuat jati diri bangsa melalui penerapan pendidikan karakter, memberikan saran dan solusi berdasarkan kajian akademik terhadap kebutuhan, tantangan, atau persoalan yang dihadapi masyarakat (Khasanah \& Herina, 2019), sehingga baik secara langsung maupun tidak langsung dapat memberikan manfaat dalam memberikan keterangan yang lebih dalam tentang keadaan sosial masyarakat Jajaran Baru II Kecamatan Megang Sakti Kabupaten Musi Rawas Tahun 2020.

\section{Metode Pelaksanaan}

Workshop diselenggarakan dengan ceramah, tanya jawab, dan memberi solusi. Ceramah dan Tanya Jawab. Metode ini bertujuan untuk menyampaikan rangkaian teori tentang cara berorganisasi yang baik dan materi pendidikan karakter yang tertuang dalam slide video. Pemutaran slide video tentang pendidikan karakter saat ini. Pada sesi ini, solusi merupakan saran dan masukan terhada peran orangtua dalam menerapkan pendidikan karakter terhadap generasi muda.

Tempat pengabdian pada masyarakat adalah di Desa Jajaran Baru II Kecamatan Megang Sakti Kabupaten Musi Rawas. Tanggal pelaksanaan kegiatan pengabdian pada masyarakat ini adalah tanggal 14 Oktober 2020 sampai tanggal 3 Maret 2020. Mitra kerja dalam pengabdiaan pada masyarakat di Desa Jajaran Baru II. 
Kegiatan workshop ini mengundang nara sumber,yaitu Agus Susilo, M.Pd., yaitu menyampaikan konsep Pendidikan berorganisasi, Akmal Rijal, M.Pd., yaitu menyampaikan pendidikan karakter dan Azizil Fikri, M.Pd., yaitu strategi pendampingan pendidikan berorganisasi yang baik. Para narasumber merupakan Dosen-Dosen STKIP PGRI Lubuklinggau yang juga pengiat Pendidikan Berorganisasi, Pendidikan Karakter, Iptek dan teknologi. Adapun bertindak sebagai moderator dalam dalam seminar kali ini adalah Manda Marlena Saputri yang merupakan mahasiswa KKN STKIP PGRI Lubuklinggau yang sedang KKN di Desa Jajaran Baru II Kecamatan Megang Sakti Kabupaten Musi Rawas, sementara itu Hariyadi dan Popi Imelda dipercaya sebagai notulen dalam workshop ini.

Sarana dan prasarana yang digunakan dalam penyampaian materi pengabdian pada masyarakat ini adalah makalah, papan tulis, penghapus, spidol, penggaris, laptop dan LCD sebagai penunjang proses pengabdian pada masyarakat. Berdasarkan permasalahan mitra terdapat beberapa kegiatan sosialisasi untuk menangani permasalahan tersebut yaitu dapat dilihat pada tabel 1 berikut.

Tabel 1. Kegiatan sosialisasi

\begin{tabular}{llc}
\hline No & Materi & Alokasi Waktu (JP) \\
\hline 1 & Pendidikan Berorganisasi & 6 \\
& $\begin{array}{l}\text { a. RasaTanggung Jawab } \\
\text { b. Melatih Jiwa Kepemimpinan }\end{array}$ & 8 \\
& $\begin{array}{l}\text { c. Memberikan pengalaman kepada setiap anggota di dalamnya } \\
2\end{array}$ & 4 \\
Pendidikan Karakter & \\
a. Kemampuan Berorganisasi & 6 \\
b. Gambaran Global Penggunaan Internet & 8 \\
Strategi Pendampingan Pendidikan & 6 \\
Berorganisasi Yang Baik & 4 \\
a. Gambaran Penggunaan Internet Indonesia & 6 \\
b. Dampak Perkembangan Internet & \\
c. Kasus Media Sosial & Total & 48 Jam \\
\hline
\end{tabular}

\section{Hasil dan Pembahasan}

Pengabdian pada masyarakat ini dilaksanakan selama satu bulan dengan perincian sebagai berikut:

1. Pertengahan Bulan Februari, yaitu pada bulan ini akan dilakukan studi kelayakan serta perencanaan materi dan kegiatan pengabdian yang sesuai khalayak sasaran.

2. 20 Hari Bulan Februari, yaitu pada bulan kedua akan dilakukan penyusunan proposal pengabdian, perencanaan pengabdian, seleksi peserta dan konfirmasi materi dan kegiatan pengabdian yang akan dilakukan. 
3. 25 Bulan Februari, yaitu pada periode ini akan dilaksanakan segala kegiatan dan penyampaian materi sebagaimana telah dituangkan dalam perencanaan pengabdian.

4. 26 Bulan Februari, yaitu pada periode ini akan dilaksanakan segala kegiatan dan penyampaian materi sebagaimana telah dituangkan dalam perencanaan pengabdian.

5. 30 Bulan Februari, yaitu pada periode ini akan dilaksanakan segala kegiatan dan penyampaian materi sebagaimana telah dituangkan dalam perencanaan pengabdian.

6. 3 Bulan Maret, yaitu tahap ini merupakan tahap akhir pengabdian yang berisi akhir kegiatan dan proses pelaporan serta penilaian hasil kerja pengabdian.

Pengabdian pada masyarakat di Desa Jajaran Baru II Kecamatan Megang Sakti Kabupaten Musi Rawas dilaksanakan selama 4 hari yakni:

a. Sabtu, 14 Februari 2020 ( 8 Jam kegiatan)

b. Kamis, 20 Februari 2020 ( 8 Jam kegiatan)

c. Selasa, 25 Februari 2020 ( 8 Jam Kegiatan)

d. Rabu, 26 Februari 2020 ( 8 Jam Kegiatan)

Masyarakat desa sekarang dengan masyarakat desa dahulu dalam pengertian desa jelas telah mengalami perubahan, karena ada beberapa bagian dari keadaan desa yang berubah seiring perubahan dalam pembangunan bangsa dan pembangunan desa khususnya. Perubahan dalam pola fisik maupun perubahan dalam pola-pola budaya yang berkembang. Perubahan dalam pola-pola budaya menjadi akar dalam perubahan pola orientasi dan status desa menjadi kota, perubahan dalam fisik juga merubah pola penyebutan desa menjadi istilah semikota dan kota karena berbagai pemenuhan kelengkapan fasilitas umum yang harus dipenuhinya.

Saat ini Desa Jajaran Baru Kecamatan Megang Sakti merupakan salah satu desa yang mengalami kemajuan yang sangat signifikan. Meskipun berada di wilayah yang pelosok jauh dari perkotaan, desa ini menjadi desa yang mandiri. Masyarakatnya banyak mengembangkan perekonomian yang tidak bertumpu pada perkebunan karet saja, namun juga industri kecil seperti pembuatan gula merah kelapa, dan berbagai industri lainnya. Maka generasi muda perlu sebuah pengalaman ilmu dalam berorganisasi yang baik agar perkembangan ekonomi yang menyangkut hajat orang banyak memberikan manfaat bagi kehidupan masyarakat Desa Jajaran Baru. Dalam situasi seperti itu, erosi nilai-nilai kemanusiaan perlu diwaspadai. Semakin dominannya nilai ekonomis dalam masyarakat atau semakin merajalelanya arus komersialisasi diberbagai bidang kehidupan dan semakin nilai-nilai kemanusiaan terancam. Selain itu untuk menghadapi era industry yang semakin maju, generasi muda Desa Jajaran Baru harus memiliki kemampuan dalam menjaga sikap, mawas diri, dan bertingkah laku bagi yang mana tertuang dalam pendidikan karakter. Sangat penting pendidikan karakter harus dikembangkan sejak dini bagi perkembangan masyarakat.

Pengabdian pada masyarakat ini merupakan program tahunan bagi dosen di lingkungan STKIP PGRI Lubuklinggau untuk melaksanakan Tri Dharma Perguruan Tinggi. Pengabdian pada masyarakat tentang penyuluhan Pendidikan karakter di era globalisasi pada masyarakat Desa Jajaran Baru Kecamatan Megang Sakti Kabupaten Musi Rawas untuk mengimbangi pengaruh globalisasi yang semakin deras mempengaruhi kaum 
muda. Desa Jajaran Baru Kecamatan Megang Sakti Kabupaten Musi Rawas dipilih sebagai tempat pengabdian pada masyarakat karena semangat berorganisasinya sangat tinggi namun membutuhkan arahan yang baik dan berkarakter serta memiliki generasi muda yang penuh jiwa semangat yang tinggi dan berada di daerah yang dekat Kota Lubuklinggau, dimana merupakan tempat bertukarnya budaya yang masuk dilingkungan masyarakat.

Dukungan lembaga desa dan masyarakat Desa Jajaran Baru Kecamatan Megang Sakti menjadi tolak ukur dilaksanakan pengabdian pada masyarakat oleh Dosen-Dosen STKIP PGRI Lubuklinggau. Perguruan Tinggi. Pengabdian pada masyarakat tentang penyuluhan Pendidikan karakter di era globalisasi pada masyarakat Desa Jajaran Baru Kecamatan Megang Sakti Kabupaten Musi Rawas untuk mengimbangi pengaruh globalisasi yang semakin deras mempengaruhi kaum muda. Desa Jajaran Baru Kecamatan Megang Sakti Kabupaten Musi Rawas dipilih sebagai tempat pengabdian pada masyarakat karena semangat berorganisasinya sangat tinggi namun membutuhkan arahan yang baik dan berkarakter serta memiliki generasi muda yang penuh jiwa semangat yang tinggi dan berada di daerah yang dekat Kota Lubuklinggau, dimana merupakan tempat bertukarnya budaya yang masuk dilingkungan masyarakat. Dukungan lembaga desa dan masyarakat Desa Jajaran Baru Kecamatan Megang Sakti menjadi tolak ukur dilaksanakan pengabdian pada masyarakat oleh Dosen-Dosen STKIP PGRI Lubuklinggau. Dalam menyampaikan paparannya dalam kegiatan pengabdian masyarakat di Desa Jajaran Baru II Kecamatan Megang Sakti Kabupaten Musi Rawas, peserta yang diharapkan hadir sekitar 15 orang.

Kriteria sasaran yang akan mengikuti sosialisasi pendidikan berorganisasi dan pendidikan karakter di Desa Jajaran Baru II Kecamatan Megang Sakti Kabupaten Musi Rawas merupakan para generasi muda dan tua yang terdiri dari para masyarakat biasa, perangkat Desa, Karang Taruna, dan mahasiswa KKN STKIP PGRI Lubuklinggau yang sedang melaksanakan KKN di Desa Jajaran Baru II. Cara rekrutmen sasaran ini ialah dengan bekerjasama dengan mahasiswa KKN STKIP PGRI Lubuklinggau, Kepala Desa/Lurah, perangkat Desa dan Karang Taruna di Desa Jajaran Baru II.

Kecamatan Megang Sakti Kabupaten Musi Rawas adalah Lurah, Kepala Desa, karang Taruna dan masyarakat umum di wilayah pengabdian pada masyarakat ini. Bentuk kemitraan yang terjalin ini berupa kerjasama yang baik adanya kerjasama antara di Desa Jajaran Baru II Kecamatan Megang Sakti Kabupaten Musi Rawas dengan pihak STKIP PGRI Lubuklinggau.

Hasil sosialisasi ini menghasilkan beberapa rekomendasi sebagai berikut. Bahwa dengan masyarakat Desa Jajaran Baru II Kecamatan Megang Sakti Kabupaten Musi Rawas harus pandai berkomunikasi dalam membangun dunia organisasi, hidup rukun, dan tetap menjadi penduduk yang arif, bijaksana dan berkarakter. Pengaruh globalisasi yang masuk ke dalam lingkungan masyarakat tidaklah selalu buruk, namun ada yang memiliki dampak positif bagi perkembangan zaman. Namun masyarakat harus cerdas dan tanggap dalam menyaring pengaruh budaya asing dan jangan sampai budaya luar mampu menghilangkan budaya lokal bangsa.

Masyarakat Desa Jajaran Baru II Kecamatan Megang Sakti Kabupaten Musi Rawas yang mayoritas penduduk transmigrasi dari pulau Jawa merupakan masyarakat yang mengandalkan pertanian dan perkebunan sebagai penyambung perekonomian 
hidupnya. Masyarakat juga telah banyak mengenal pendidikan tinggi bahkan tidak jarang generasi muda lulusan perguruan tinggi yang memiliki pemikiran yang lebih luasa. Pengaruh globalisasi sangat rentan bagi generasi muda saat ini, tidak jarang pengaruh negatf masuk dengan bebas pada generasi muda saat ini. Maka dari itu diperlukan pendidikan karakter sebagai benteng untuk menahan derasnya pengaruh globalisasi yang sangat berbahaya tersebut.

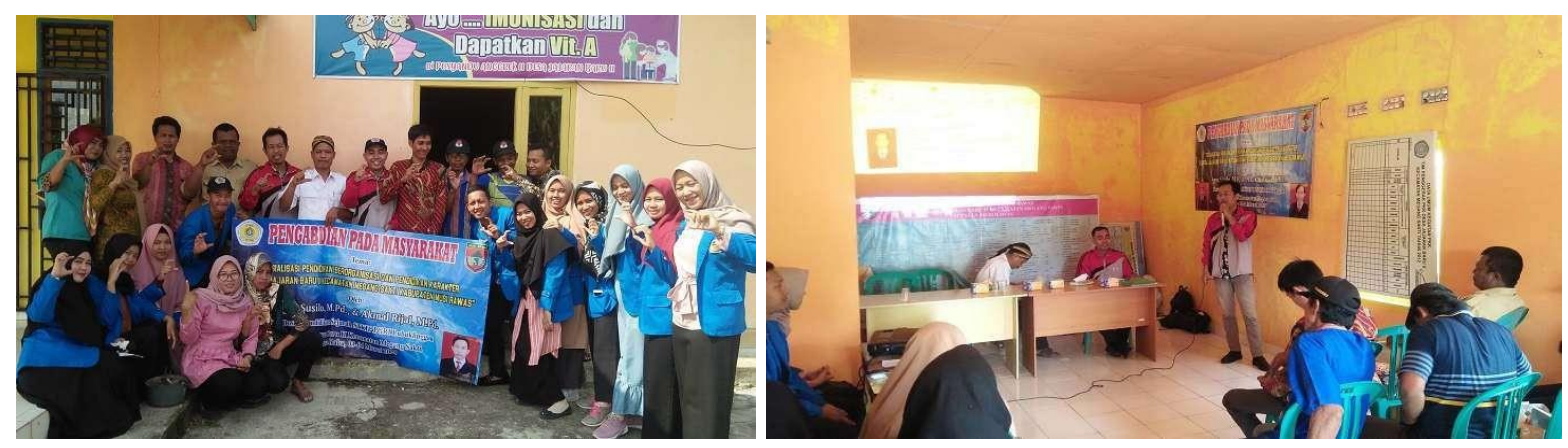

Gambar 1. Dokumentasi kegiatan PKM

Masyarakat Desa Jajaran Baru II Kecamatan Megang Sakti Kabupaten Musi Rawas sangat menjunjung tinggi nilai budaya dan sopan santun, namun demikian pengaruh asing atau globalisasi tidak luput dari kehidupan masyarakatnya. Masyarakat yang berkarakter perlu diciptakan dengan baik dan benar karena dalam masyarakat anak akan mengenal dan mengetahui pengetahuan tambahan, pengganti dari pendidikan lingkungan lain, sehingga masyarakat perlu paham akan pentingnya peranan dalam membangun pendidikan karakter bagi anak. Masyarakat yang berkarakter akan mendukung segala upaya dalam menunjang pendidikan yang layak bagi anak dan masyarakat juga akan mengikutsertakan setiap individu dalam lingkungannya untuk bekerjasama memperbaiki kualitas pendidikan Indonesia. Masyarakat berkarakter tahu bagaimana caranya menciptakan suasana pendidikan yang tepat bagi sekitarnya sehingga perannya sebagai agen pendidikan dengan optimal.

\section{Kesimpulan}

Berdasarkan hasil evaluasi terhadap seluruh kegiatan yang telah dilaksanakan menyampaikan konsep pendidikan berorganisasi, pendidikan karakter, dan strategi pendampingan pendidikan berorganisasi yang baik maka dapat disimpulkan bahwa seluruh kegiatan menunjang peningkatan pengetahuan dan keterampilan dalam keberlangsungan membangun pendidikan berorganisasi dan pendidikan karakter bagi genarasi muda terhadap pengaruh era industry yang semakin luas agar dapat menjadi generasi muda yang berilmu dan mampu memfilter segala pengaruh luar yang masuk dilingkungan ekonomi, politik, sosial dan budaya masyarakat, mendiseminasikan hasilhasil pengabdian pada masyarakat STKIP PGRI Lubuklinggau yang dapat dimanfaatkan untuk memperkuat jati diri bangsa melalui penerapan pendidikan karakter, memberikan saran dan solusi berdasarkan kajian akademik terhadap kebutuhan, tantangan, atau persoalan yang dihadapi masyarakat, baik secara langsung maupun tidak langsung, dan memberikan manfaat dalam memberikan keterangan yang lebih dalam tentang keadaan sosial masyarakat Jajaran Baru II Kecamatan Megang Sakti Kabupaten Musi Rawas Tahun 2020. 


\section{Ucapan Terimakasih}

Kegiatan pengabdian ini mendapat dukungan dari berbagai pihak. Sehubungan dengan hal tersebut penulis mengucapkan terima kasih kepada mitra kegiatan ini yaitu pemerintah Desa dan masyarakat Jajaran Baru II Kecamatan Megang Sakti Kabupaten Musi Rawas Tahun 2020 dan STKIP PGRI Lubuklinggau yang telah memberikan kesempatan kepada kami untuk mendapatkan bantuan pendanaan kegiatan Pengabdian kepada Masyarakat ini.

\section{Referensi}

Albertus, D. K. (2015). Pendidikan Karakter Utuh dan Menyeluruh. Yogyakarta: Kanisius.

Asmani, J. M. (2012). Buku Panduan Internalisasi Pendidikan Karakter di Sekolah. Jogjakarta: Diva Press.

Khasanah, U., \& Herina, H. (2019). Membangun Karakter Siswa Melalui Literasi Digital DalamMenghadapi Pendidikan Abad 21 (Revolusi Industri 4.0). Prosiding Seminar Nasional Pendidikan Program Pascasarjana Universitas PGRI Palembang.

Kristiawan, M., Suryanti, I., Muntazir, M., \& Ribuwati, A. (2018). Inovasi Pendidikan.Jawa Timur. Wade Group National Publishing.

Kementerian Riset, Teknologi, dan Pendidikan Tinggi. (2017). Pedoman Publikasi llmiah. Jakarta: Direktorat Pengelolaan Kekayaan Intelektual.

Rusman, R. (2013). Model-Model Pembelajaran (Mengembangkan Profesionalisme Guru). Jakarta: PT Raja Grafindo Persada.

Subekti, S. (2018). Pendidikan Sepanjang Hayat. Jakarta : PT Intermasa.

Trianto, T. (2012). Model Pembelajaran Terpadu. Jakarta: Bumi Aksara. 